\title{
Parasite structure of the Ocean Whitefish Caulolatilus princeps from Baja California, México (East Pacific)
}

\author{
M. A. Rodríguez-Santiago · J. A. Rosales-Casián
}

Received: 17 December 2009 / Accepted: 13 July 2010 / Published online: 28 July 2010

(C) Springer-Verlag and AWI 2010

\begin{abstract}
The metazoan parasite fauna of Caulolatilus princeps from northern Baja California, Mexico is quantitatively described for the first time. Further, the ecological aspects of prevalence, abundance, and intensity of infection are examined through an annual cycle. Six parasite species were recorded; 2 ectoparasites ( 1 monogenean and 1 copepod) and 4 endoparasites ( 2 digeneans and 2 nematodes). The digeneans Choanodera caulolatili and Bianium plicitum, the nematodes Anisakis sp. and Hysterothylacium sp., and the copepod Hatschekia sp. set new geographical and host records. The highest values of prevalence and abundance were in Anisakis sp. (prevalence $=93.3 \%$, abundance $=12.4 \pm 4.7 \mathrm{ind} / \mathrm{host}$ ) and in Hysterothylacium sp. $($ prevalence $=86.6 \%$, abundance $=16.5 \pm 3.4 \mathrm{ind} / \mathrm{host}$ ). The mean intensity of infection showed maximum values in summer (August $=14.2$ ) and minimums in winter (February $=4.2$ ). The mean intensity was higher in Hatschekia sp. (20.3 \pm 7.8$)$ followed by Hysterothylacium sp. $(18.6 \pm 1.4)$ and Anisakis sp. (12.9 \pm 2.2$)$. Larval stages of Anisakis and Hysterothylacium were particularly important
\end{abstract}

Communicated by Kurt Thomas Jensen.

M. A. Rodríguez-Santiago ( $\square$ )

Facultad de Ciencias Marinas,

Universidad Autónoma de Baja California,

Km 106 carretera Tijuana-Ensenada,

C.P. 22800 Ensenada, BC, México

e-mail: amparor@cicese.mx

J. A. Rosales-Casián

División de Oceanología,

Departamento de Ecología Marina, Centro de Investigación

Científica y de Educación Superior de Ensenada BC,

Km 107 carretera Tijuana-Ensenada,

C.P. 22800 Ensenada, BC, México due to their high abundance and prevalence, because they represent a human health risk (anisakiasis). In addition, the relationships between the metazoan parasites of $C$. princeps and host size and weight, fish condition and water temperature (bottom) are discussed.

Keywords Parasites - Caulolatilus princeps · Prevalence · Abundance $\cdot$ Intensity of infection $\cdot$ Mexico

\section{Introduction}

Knowledge about the parasite fauna of marine fishes from the Mexican Pacific coasts is still scarce (Pérez-Ponce de León et al. 1999; Sánchez-Ramírez and Vidal-Martínez 2002). The ocean whitefish, Caulolatilus princeps (Malacanthidae), ranges from Vancouver Island in British Columbia (Canada) to Peru, including the Galapagos Islands (Dooley 1978), and inhabits rocky reefs from 10 to 150 m depth (Hammann and Rosales-Casián 1990).

In the northwestern coasts of Mexico (both coasts of Baja California peninsula), this fish species is caught all year by coastal commercial and recreational fishing (Elorduy-Garay and Ruiz-Córdova 1998; Rosales-Casian and Gonzáles-Camacho 2003; Siri-Chiesa and MoctezumaHernández 1989); the C. princeps catch during 2000 from Baja California Sur constituted 1,073 tons, 93\% of the total catch for this species in Mexico (SAGARPA 2002). However, studies have focused on growth (Elorduy-Garay and Ramírez-Luna 1994), reproduction (Elorduy-Garay and Peláez-Mendoza 1996), and feeding (Elorduy-Garay et al. 2005), whereas the parasite community is poorly studied.

Therefore, the goals of the present study are (1) to identify the parasite fauna on $C$. princeps from the northwestern coasts of Baja California (México), (2) to determine the 
parasite community structure by their prevalence, abundance, intensity of infection and its variability through an annual cycle, and (3) to determine the relationships between parasite abundance and host size and weight, condition factor and water temperature.

\section{Materials and methods}

Ocean whitefish specimens were captured in the coast of San Quintín, Baja California, México by sport-fishing boats during 2005. The fishing area is in the Pacific Ocean out-

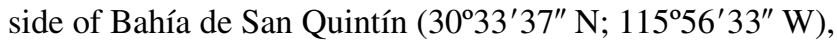
located $310 \mathrm{~km}$ south from the California border (USA) and $6 \mathrm{~km}$ from El Molino Viejo harbor (Old Mill). Fishing harvests pelagic and bottom fish species (Rosales-Casian and Gonzáles-Camacho 2003; Rodríguez-Santiago and Rosales-Casián 2008) from surface to $150 \mathrm{~m}$ depth and as far as $50 \mathrm{~km}$ from rocky point Punta Entrada, outside of the bay. The whitefish individuals were captured from different rocky reefs in the area with random sampling which was dependent upon the boat catches.

Surface water temperatures $\left({ }^{\circ} \mathrm{C}\right)$ during 2005 were obtained from boat captain reports. Temperatures at 50-140 m depth were obtained from station 107.32 of the IMECOCAL cruises (Lat. 30 27.288' N, Long. 116 ${ }^{\circ} 9.696^{\prime}$ W), located close to Isla San Martin (García-Córdova et al. 2005).

The site was sampled bimonthly, and parasite information was grouped by seasons: spring (April and June), summer (August), autumn (October), and winter (December and February). Ocean whitefish was identified using Miller and Lea (1972). All specimens were measured using total length $(\mathrm{mm}, \mathrm{LT})$ and weighed $(\mathrm{g})$ with a digital balance Accu-Lab (6 kg); whitefish individuals ranged 370-510 mm LT, those lengths represented a range of 13-21 years old (Elorduy-Garay et al. 2005; Manríquez-Ledezma 2009). The Fulton's Condition Factor (Ricker 1975) was calculated for each specimen of $C$. princeps as: $K=\left[W / \mathrm{TL}^{3}\right]$ 100,000 where: $W=$ weight $(\mathrm{g})$ and $\mathrm{TL}=$ total length (mm).

Specimens were dissected, and organs stored in plastic bags on ice. In the laboratory, internal organs (gills, liver, spleen, intestine, pyloric cecum, heart, gonads, and digestive tract) and external structures (skin and fins) were examined under a stereoscopic microscope, and all parasites were removed. Monogeneans and digeneans were fixed in AFA (acetic acid-formaldehyde-alcohol) solution for $2-24 \mathrm{~h}$, then preserved in ethylic alcohol $(70 \%)$, and stained with Gomori's trichromic stain (Vidal-Martínez et al. 2002). Nematodes were fixed in Berland's liquid, preserved in ethylic alcohol (70\%), cleared with a solution of phenol-ethanol (Lent's solution), and mounted on slides covered with glycerin-gelatin (Moravec et al. 1992). Copepods were first fixed in ethylic alcohol (70\%), then cleared using a solution of glycerin-alcohol, and mounted on slides covered with glycerin-gelatin.

Identification of parasites was made using keys proposed by Yamaguti (1961, 1963, 1971), Vidal-Martínez et al. (2002), Bravo-Hollis (1967, 1982a, b) and Anderson et al. (1974-1983). To determine genera, Cressey and Boyle (1980, 1985), Kabata (1979, 1992a, b), and Boxshall (2004) were used. The parasitological material was deposited in the Laboratorio de Ecología Pesquera of the Centro de Investigación Científica y de Educación Superior de Ensenada, Baja California (CICESE), México.

Prevalence (\%), abundance (number of parasites per host), and intensity (number of parasites/infected hosts) of parasites were determined according to Margolis et al. (1982). To assess significant variations in the mean abundance of parasites over seasons, a non-parametric analysis of variance of Kruskall-Wallis (KW) was performed (Steel and Torrie 1986). Spearman rank correlations were used to assess relationships between the abundance of parasites and host size and weight, fish condition and water temperature (bottom).

\section{Results}

Surface water temperature $\left({ }^{\circ} \mathrm{C}\right)$ in the area showed a mean $( \pm \mathrm{SE})$ of $16.0 \pm 0.3^{\circ} \mathrm{C}$. The highest temperature mean was in August $\left(18.2 \pm 0.5^{\circ} \mathrm{C}\right)$, and lowest in February $\left(14.9 \pm 0.3^{\circ} \mathrm{C}\right)$. At fishing depth $(50-140 \mathrm{~m})$, annual temperature mean was $10.9 \pm 0.09^{\circ} \mathrm{C}$ with highest in October $\left(11.5 \pm 0.20^{\circ} \mathrm{C}\right)$ and lowest in June $\left(10.2 \pm 0.08^{\circ} \mathrm{C}\right)$.

Species composition and organ specificity on C. princeps

A total of 91 specimens of $C$. princeps were examined (spring $=15$ individuals; summer $=16$; autumn $=38$; and winter $=22$ ). A total number of 3,820 parasites, belonging to 6 parasite species were identified (Table 1). They were 1 monogenean (Choricotyle caulolatili), 2 digeneans (Choanodera caulolatili and Bianium plicitum), 2 larval stages of nematodes (Anisakis sp. and Hysterothylacium sp.), and 1 copepod (Hatschekia sp.). The scientific names of Choanodera caulolatili and Choricotyle caulolatili are stated in full to avoid confusion.

The digestive tract was the most infested organ with 4 species. Choanodera caulolatili and B. plicitum were found in intestine and stomach. Choricotyle caulolatili and Hatschekia sp. were found on gills. Anisakis sp. was found in mesentery. Larvae of Hysterothylacium sp. were found in mesentery, stomach, intestine, and cecum (Table 1). 
Table 1 Characterization of parasitic infections of Caulolatilus princeps from the coasts of San Quintin, Baja California, Mexico

\begin{tabular}{|c|c|c|c|c|c|c|c|}
\hline Parasites & $\mathrm{NF}$ & $\mathrm{PF}$ & TNP & $\mathrm{P}$ & MA & MI & $\mathrm{L}$ \\
\hline \multicolumn{8}{|l|}{ Monogenea } \\
\hline Choricotyle caulolatili & 91 & 12 & 17 & 13.2 & $0.2 \pm 0.1$ & $2.6 \pm 1.3$ & G \\
\hline \multicolumn{8}{|l|}{ Digenea } \\
\hline Bianium plicitum & 91 & 57 & 247 & 62.6 & $2.7 \pm 0.1$ & $4.9 \pm 1.1$ & I \\
\hline Choanodera caulolatili & 91 & 34 & 108 & 37.3 & $1.3 \pm 0.1$ & $3.5 \pm 0.9$ & $\mathrm{I}, \mathrm{S}$ \\
\hline \multicolumn{8}{|l|}{ Nematoda } \\
\hline Anisakis sp. & 91 & 84 & 1,113 & 92.3 & $12.4 \pm 4.7$ & $12.9 \pm 2.2$ & M \\
\hline Hysterothylacium sp. & 91 & 78 & 1,462 & 85.7 & $16.5 \pm 3.5$ & $18.6 \pm 1.4$ & $\mathrm{M}, \mathrm{S}, \mathrm{I}, \mathrm{IC}$ \\
\hline \multicolumn{8}{|l|}{ Copepoda } \\
\hline Hatschekia sp. & 91 & 52 & 873 & 57.1 & $10.1 \pm 1.9$ & $20.3 \pm 7.8$ & G \\
\hline
\end{tabular}

Total number of fishes examined $(N F)$, number of fishes parasitized $(P F)$, total number of parasites per taxa $(T N P)$, percentage of prevalence $(P)$. Mean abundance $(M A)$ and mean intensity $(M I)$ of parasites $( \pm \mathrm{SE})$ were calculated from mean values of seasons. Localization $(L)$ in the host body; $G$ Gills; IC Intestinal cecum; $S$ Stomach; $I$ Intestine; $M$ Mesentery

\section{Prevalence}

The nematodes Anisakis sp. and Hysterothylacium sp. showed the highest prevalences $(93.3$ and $86.6 \%$, respectively), and the monogenean Choricotyle caulolatili the lowest (13.3\%); the species B. plicitum, Anisakis sp., and Hysterothylacium sp. had prevalences higher than $60 \%$ and were considered as principal species; Hatschekia sp. and Choanodera caulolatili were secondary species (58 and $38 \%$, respectively), and Choricotyle caulolatili with a prevalence of $13.3 \%$ was considered a satellite species (Table 1).

From late winter to autumn (February-October), Anisakis sp. showed a prevalence of $100 \%$ and a decrease (72\%) in early winter (December) (Fig. 1a). Similarly, Hysterothylacium sp. exhibited prevalences of $100 \%$ from late winter to summer (from February to August), a slight decrease in autumn (95\%, October), and an abrupt diminution in December (50\%). The other species such as Hatschekia sp., B. plicitum, Choanodera caulolatili, and Choricotyle caulolatili showed an abrupt decrease in prevalence from spring to summer (Fig. 1a).

Abundance and intensity of parasites

The most abundant parasite species was Hysterothylacium sp. with a total of 1,462 individuals, and the lowest number was Choricotyle caulolatili with 17 individuals (Table 1). The overall mean abundance $( \pm \mathrm{SE})$ of parasites on $C$. princeps was $7.2 \pm 0.7 \mathrm{ind} / \mathrm{host}$, and seasonal mean abundances showed significant changes over time (Kruskall-Wallis, $H=22.20, P=0.0001)$. Hysterothylacium sp. showed the highest overall mean abundance (calculated from average values of seasons) $(16.5 \pm 3.5 \mathrm{ind} / \mathrm{host})$, followed by Anisakis sp. $(12.4 \pm 4.7 \mathrm{ind} / \mathrm{host})$, Hatschekia sp. $(10.1 \pm 1.9$ ind/host), B. plicitum (2.7 $\pm 0.1 \mathrm{ind} / \mathrm{host})$, Choanodera caulolatili (1.3 $\pm 0.1 \mathrm{ind} / \mathrm{host})$, and Choricotyle caulolatili $(0.2 \pm 0.1$ ind/host) (Fig. 1b).

The abundance of Hysterothylacium sp. was higher in late spring (21.6 ind/host) and lower in winter ( $7.8 \mathrm{ind} /$ host), while Anisakis sp. showed the highest abundance in spring (16.4 ind/host) and lowest in winter (5.5 ind/host) (Fig. 1b). With respect to species, only the mean abundances of Anisakis sp. showed significant changes (KruskallWallis, $H=11.05, P=0.011$ ) with the seasons.

With respect to the intensity of parasite infection, the highest mean value was exhibited by Hatschekia sp. (20.3 \pm 7.8$)$, followed by Hysterothylacium sp. (18.6 \pm 1.4$)$, and Anisakis sp. $(12.9 \pm 2.2)$; the rest of species had intensity values lower than 10 (Table 1). In the case of Hatschekia sp., the intensity increased from spring (14.6) to summer (40.2), which then decreased in winter (10.5). Hysterothylacium sp. showed the highest intensity in spring (21.6), followed by a decrease to the lowest (15.6) in winter (Fig. 1c). The rest of parasite species did not show important variations over time (Fig. 1c).

The Spearman rank correlations showed a significant positive correlation between prevalence and parasite abundance $(r=0.943, P<0.05)$. Also, a significant correlation between the abundance of the nematode Hysterothylacium sp. and the surface water temperature $(r=0.880, P<0.05)$ was detected. In addition, a significant negative correlation was found between the overall parasite abundance and the $50-140 \mathrm{~m}$ depth temperature $(r=-0.829, P<0.05)$. No correlations were found between the abundance of parasites with the host size and weight, and with fish condition.

\section{Discussion}

Four parasite species had been reported for ocean whitefish: 2 monogeneans: Choricotyle caulolatili (as Diclidophora 

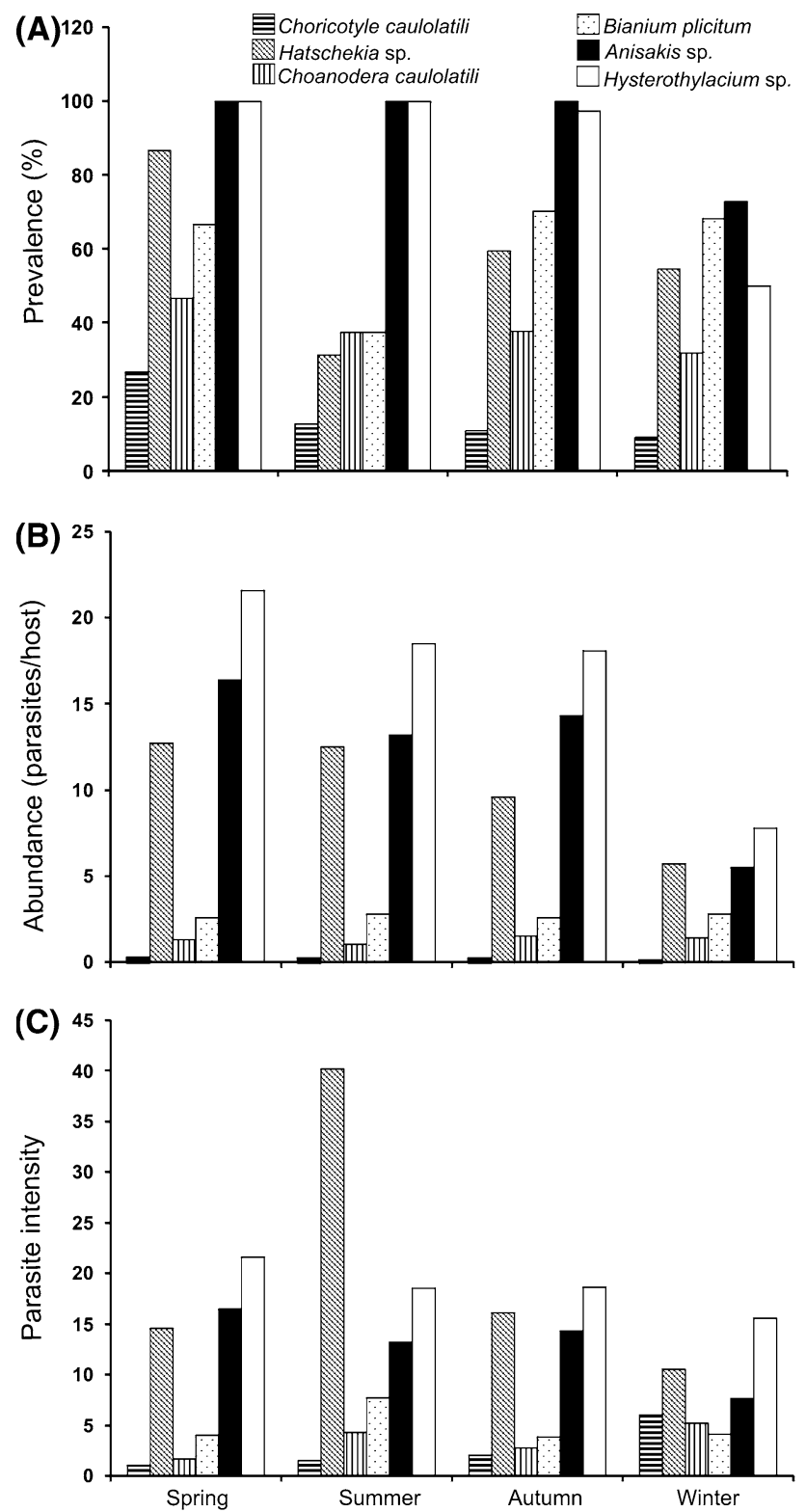

Fig. 1 a Prevalence (\%), b abundance (parasites/host) and $\mathbf{c}$ intensity of parasites on specimens of Caulolatilus princeps collected at San Quintín, Baja California, during an annual cycle, 2005

caulolatili, Meserve 1938) in Galapagos Islands (Merseve 1938) and Jaliscia caballeroi in Sonora Mexico (BravoHollis 1982c), 1 digenean: Proctoeces magnorus in Isla Cedros Baja California, Mexico (Winter-Howard 1959), and 1 parasitic copepod: Brachiella gracilis in Ensenada, Baja California, México (Causey 1960). In our study, Choanodera caulolatili, B. plicitum, Hysterothylacium sp., Choricotyle caulolatili, and Hatschekia sp. constitute new geographical records and Anisakis sp., B. plicitum, Hysterothylacium sp., and Hatschekia sp. were new host records.

The parasite composition of $C$. princeps was represented by 6 species, where digeneans contributed with 2 species and $40 \%$ of the total individuals, this group of parasites are frequent in marine fishes (Rhode 1982; Castillo-Sánchez et al. 1998; Sánchez-Ramírez and Vidal-Martínez 2002; Muñoz et al. 2006).

The trematode species are common in marine and estuarine fishes of California, Oregon, and Washington (Love and Moser 1983). In the estuarine fish Mugil cephalus, a trematode frequency of $50 \%$ was found, and similar values in fishes from families Sciaenidae (Leiostomus xanthurus and Micropogonias undulatus), Scombridae (Euthynnus lineatus), and Khyphosidae (Khyphosus elegans) (Thoney 1993; León-Regagnon et al. 1997; Juárez-Arroyo and Salgado-Maldonado 1989). Parasite community structure may be influenced by factors such as the host biology, benthic habitat and territorial behavior (González and Poulin 2005).

The nematodes are important in fish parasitic diseases and are frequently found in different organs or microhabitats (Love and Moser, 1983; Alvarado-Villamar and Ruiz-Campos 1992; Thoney 1993; Castillo-Sánchez et al. 1998; Aloo et al. 2004). In the present study, parasites with high specificity were the ectoparasites Choricotyle caulolatili and Hatschekia sp., which were found on gills only; Anisakis sp. and B. plicitum were found in the mesentery and intestines, respectively. This specificity could be due to the kind of nutrients that these organs offer.

Larvae of Hysterothylacium sp. and Anisakis sp. were the most abundant parasites in the ocean whitefish and accounted for $67.4 \%$ of total parasites. Most parasite groups, which infect marine fishes, are at adult stages, indicating that fishes are important as final hosts rather than as intermediate hosts (Juárez-Arroyo and Salgado-Maldonado 1989; Castillo-Sánchez et al. 1998; León-Regagnon et al. 1997). Previous studies have suggested that some parasites of $C$. princeps come from larvae hosted in intermediate hosts such (mollusk gasteropods, cephalopods, fishes), which harbor mainly digeneans whose abundance depends on diet (Elorduy-Garay et al. 2005). Furthermore, demersal fish studies indicated that many species are intermediate links in the marine food chain (Muñoz et al. 2006; Oliva and Luque 1998; Cordeiro and Luque 2004; SánchezRamírez and Vidal-Martínez 2002).

In this study, larvae of Hysterothylacium sp. showed higher values of prevalence $(87 \%)$ and parasite intensity (18.5 parasites/fish infected) than those reported for Hysterothylacium aduncum in Chilean salmon farms (prevalence $=79.1 \%$; mean intensity $=4.9$ parasites $/$ fish infected) (González 1998). A common pattern in marine fish is that parasite intensity shows variability by species complexity with low prevalences and abundances (Valtonen et al. 2001; Tavares and Luque 2004).

Our study indicated that parasite abundance was not correlated with size of $C$. princeps; however, we did not analyze smaller sizes that are unavailable for sport-fishing. 
Nevertheless, Poulin (2000) documented a significant correlation between fish length and intensity of infection for cestodes, larval digeneans, and gnathiid isopods. The condition of $C$. princeps was also independent of number of parasites hosted. This independence was similar to brown trout (Salmo trutta) from Fernworthy, Devon, United Kingdom (Kennedy and Lie 1976), where the parasites did not alter the condition.

Finally, larvae of Hysterothylacium sp. and Anisakis sp. were relatively abundant in the ocean whitefish and were important for the anthropocenoses that can develop. These parasite species can be infective to humans and cause Anisakiasis, and fish which have been infected with Anisakis spp. can produce an anaphylactic reaction in people who have become sensitized to immunoglobulin E (DomínguezOrtega et al. 2001). Therefore, we recommend not eating raw or inadequately cooked fish. The present study is the first parasitological record for this fish species in the northwestern coasts of Baja California. Further, our results on the prevalence, abundance, and intensity of parasites over an annual cycle helped us to diagnose the health status of this important marine fish for the region.

Acknowledgments This study was funded by the CICESE project: Analysis of the recreative sport-fishing catches from San Quintín, B.C., Mexico and by the UCMEXUS-CONACYT grant project: Baseline study of the nearshore non-reef fishes of Bahía de Los Angeles, Baja California, México, prior to proposed development. A. RodríguezSantiago thanks to CONACYT by the financial support (grant). We are grateful to Karen Englander (Faculty of Languages, University of Baja California) for her English review and editing of the manuscript and to F. Garcia-Vargas for his assistance with the identification of parasites. Authors also thanks to E. Fajer (CIAD-Unidad Mazatlan) and Gorgonio Ruiz (UABC) by providing us materials and equipment in their respective laboratories.

\section{References}

Aloo PA, Anam RO, Mwangi JN (2004) Metazoan parasites of some commercially important fish along the Kenyan coast. West Indian Ocean J Mar Sci 3:71-78

Alvarado-Villamar MR, Ruiz-Campos G (1992) Estudio comparativo del grado de infección de macroparásitos en seis especies de Sebastes (Pisces Scorpenidae) de la costa Noroccidental de Baja California, México. Cien Mar 18:79-92

Anderson RC, Chabaud AG, Willmott S (eds) (1974-1983) CIH keys to the nematode parasites of vertebrates, vol 1-10. Commonwealth Agricultural Bureaux, Farnham Royal, Bucks: England

Boxshall GA (2004) An introduction to copepod diversity. Ray Society Series 166. With SH. Halsey. 2 Parts, vols. The Ray Society of London, United Kingdom, p 940

Bravo-Hollis M (1967) Helmintos del Pacífico mexicano XXV. Descripción de tres monogéneos del Golfo de California. Anal Inst Biol Univ Nac Aut Méx Ser Zool 37:107-123

Bravo-Hollis M (1982a) Helmintos de peces del Pacífico mexicano XXXVII. Sobre seis especies conocidas de monogéneos del Suborden Microcotylinea Lebedev, 1972. Anal Inst Biol Univ Nac Aut Méx Ser Zool 52:1-12
Bravo-Hollis M (1982b) Helmintos de peces del Pacífico mexicano XXXIX. Estudio de Monogéneos del suborden Microcotylinea Levedev, 1972, con la presentación de una subfamilia y una especie nuevas. Anal Inst Biol Univ Nac Aut Méx Ser Zool 53:13-26

Bravo-Hollis M (1982c) Helmintos de peces del pacifico Mexicano. XXXIX. Dos subfamilias nuevas de Monogéneos de la familia Macrovalvitrematidae Yamaguti, 1963. Anal Inst Biol Univ Nal Aut Mex Ser Zool 52:27-38

Castillo-Sánchez E, Rosales-Casián J, Pérez-Ponce de León G (1998) Helminth parasites of Paralychthys californicus (Osteichthyes: Paralichthydae) in Estero de Punta Banda, Todos Santos Bay and San Quintín Bay, Baja California, México. Cien Mar 24:443-462

Causey D (1960) Parasitic Copepoda from Mexican coastal fishes. Bull Mar Sci Gulf Caribb 10:323-337

Cordeiro AS, Luque JL (2004) Community ecology of the metazoan parasites of Atlantic moonfish, Selene setapinnis (Osteichthyes: Carangidae) from the costal zone of the State of Rio de Janeiro, Brazil. Braz J Biol 64:399-406

Cressey R, Boyle-Cressey H (1980) Parasitic copepods of Mackereland tuna-like fishes (Scombridae) of the world. Smith Contrib Zool 311:54-61

Cressey R, Boyle-Cressey H (1985) Holobomolochus (Copepoda: Bomolochidae) redefined, with descriptions of three new species from the eastern pacific. J Crust Biol 5:717-727

Domínguez-Ortega J, Alonso-Llamazares A, Rodríguez L, Chamorro M, Robledo T, Bartolomé JM, Martínez-Cócera C (2001) Anaphylaxis due to hypersensitivity to Anisakis simplex. Int Arch Allergy Immunol 125:86-88

Dooley JK (1978) Systematics and biology of the tilefishes (Periformes: Branchisoterigidae and Malacanthidae) with description of two new species. NOAA technical report. NMFS Circular 411:25-27

Elorduy-Garay JF, Peláez-Mendoza AK (1996) Hábitos alimenticios de Caulolatilus affinis, Gill 1865 (Perciformes:Branchiostegidae) en la Bahía de La Paz, B.C.S., México. Rev Biol Trop 44:241-249

Elorduy-Garay JF, Ramírez-Luna S (1994) Gonadal development and spawning of the ocean whitefish, Caulolatilus princes Jenys 1842 (Pises: Branchiosterigidae) in the Bay of La Paz, B.C.S., México. J Fish Biol 44:553-566

Elorduy-Garay JF, Ruiz-Córdova SS (1998) Age, growth, and mortality of Caulolatilus affinis (Osteichthyes: Branchiostegidae) from the Southern Gulf of California. Pac Sci 52:259-272

Elorduy-Garay JF, Ruiz-Córdova SS, Díaz JG (2005) Age, growth and mortality of Caulolatilus princeps (Pisces: Malacanthidae) from the southern Gulf of California. Hidrobiol 15:289-297

García-Córdova J, Robles-Pacheco JM, Gómez-Valdés J (2005) Informe de datos de CTD. Campaña IMECOCAL 0501/02. B/O Francisco de Ulloa. Enero 21-Febrero 10 de 2005. Informe Técnico, Departamento de Oceanografía Física CICESE, pp 132

González L (1998) The life cycle of Hysterothylacium aduncum (Nematoda: Anisakidae) in Chilean marine farms. Aquaculture 162:173-186

González MT, Poulin R (2005) Spatial and temporal predictability of the parasite community structure of a benthic marine fish along its distributional range. Int J Parasitol 35:1369-1377

Hammann GM, Rosales-Casián JA (1990) Taxonomía y estructura de la comunidad de peces del Estero de Punta Banda y Bahía de Todos Santos, B.C., México. In: Rosa-Vélez J, González-Farias (eds) Temas de Oceanografía Biológica en México. Universidad Autónoma de Baja California, Ensenada, p 337

Juárez-Arroyo AJ, Salgado-Maldonado G (1989) Helmintos de la "lisa“ Mugil cephalus Lin en Topolobampo, Sinaloa, México. Anales del Instituto de Bilogía de la Universidad Nacional Autónoma de México 60:279-298

Kabata Z (1979) Parasitic copepoda of British fishes. Ray Society, London, p 468 
Kabata Z (1992a) Copepods parasitic on fishes. Synopses of the British Fauna (new series) No. 47. Published for The Linnean Society of London and The Estuarine Coast Sci Assoc, Great Britain, p 264

Kabata Z (1992b) Copepoda parasitic on Australian fishes, XV. Family Ergasilidae (Poecilostomatoida). J Nat Hist Lond 26:47-66

Kennedy CR, Lie SF (1976) The distribution and pathogenicity of larvae of Eustrongylides (Nematoda) in brown trout Salmo trutta L in Fernworthy Reservoir Devon. J Fish Biol 8:293-302

León-Regagnon V, Pérez-Ponce de León G, García-Prieto L (1997) Description of Heteroplectanum oliveri sp n. (Monogenea: Diplectanidae) and comments on the helminth fauna of Kyphosus elegans (Perciformes: Khyphosidae) from Chamela Bay, México. J Hel Soc of Wash 64:9-16

Love MS, Moser M (1983) A checklist of parasites of California, Oregon and Washington marine and estuarine fishes. US Dept. Commer., NOAA Tech. Rep., NMFS SSRF-777, pp 576

Manríquez-Ledezma Y (2009) Edad y crecimiento de Caulolatilus princeps (Jenyns, 1840) en Bahía de La Paz y Bahía Magdalena, B.C.S. México. M.SC. Thesis, CICIMAR-IPN, La Paz BCS, México, pp 56

Margolis LG, Esch JC, Holmes AM, Kuris SchadGA (1982) The use of ecological terms in parasitology (report of an ad hoc committee of the American Society of Parasitologists). J Parasitol 68:131133

Merseve FG (1938) Some monogenetic trematodes from the Galapagos Islands and the neigh-boring Pacific. Univ South Calif Allan Hancock Found Publ Occas Pap 2:30-89

Miller DJ, Lea RN (1972) Guide to the coastal marine fishes of California. California Dept Fish and Game Fish Bull 157:1-249

Moravec FV, Nasincord, Scholz T (1992) Methods of investigation of endoparasitic helminths, Training of fish Parasites, Institute of Parasitology, Acad Sci Ceske Budejovice, p 54

Muñoz G, Grutter AS, Cribb TH (2006) Endoparasite communities of five fish species (Labridae: Cheilininea) from Lizard island: how important is the ecology and phylogeny of the host? Parasitology 132:363-374

Oliva ME, Luque JL (1998) Metazoan Parasite Infracommunities in five Sciaenids from the Central Peruvian coast. Mem Inst Oswaldo Cruz 93:175-180

Pérez-Ponce de León G, García-Prieto L, Mendoza-Garfias B, LeónRegagnon V, Pulido-Flores G, Aranda-Cruz CV, García-Vargas F (1999) Listados faunísticos de México. IX. Biodiversidad de helmintos parásitos de peces marinos y estuarinos de la Bahía de Chamela, Jalisco. Universidad Autónoma de México, México, p 51

Poulin R (2000) Variation in the intraspecific relationship between fish length and intensity of parasitic infection: biological and statistical causes. J Fish Biol 56:123-137
Rhode K (1982) Ecology of marine parasites. University of Queensland Press. St. Lucia, Queensland, p 245

Ricker WE (1975) Computation and interpretation of biological statistics of fish populations. Bull Fish Res Bd Can 191:1-382

Rodríguez-Santiago MA, Rosales-Casián JA (2008) Abundance and size composition of vermilion rockfish, Sebastes miniatus (Jordan and Gilbert 1880), from sport fishing catches of San Quintín, Ensenada, Baja California, México. Bull South Cal Acad Sci 107:25-32

Rosales-Casian JA, Gonzáles-Camacho JR (2003) Abundance and importance of Fish Species from the Artisanal Fishery on the Pacific Coast of Northern Baja California. Bull South Cal Acad Sci 102:51-65

SAGARPA (2002) Anuario Estadístico de Pesca 2000, Secretaria de Agricultura, Ganadería, Desarrollo Rural. Pesca y Alimentación, México, p 268

Sánchez-Ramírez C, Vidal-Martínez V (2002) Metazoan parasite infracommunities of Florida pompano (Trachinotus carolinus) from the coast of the Yucatán Peninsula, México. J Parasitol 8:1087-1094

Siri-Chiesa M, Moctezuma-Hernández P (1989) La pesca de Baja California. Universidad Autónoma de Baja California: México, 211

Steel RG, Torrie JH (1986) Bioestadística: principios y procedimientos. McGraw-Hill, México, p 662

Tavares LER, Luque JL (2004) Community ecology of the metazoan sea catfish, Netuma barba (Osteichthyes: Ariidae), from the costal zone of the State of Rio de Janeiro, Brazil. Braz J Biol 64:169 176

Thoney D (1993) Community ecology of the parasites of adult spot, Leistomus xanthurus and Atlantic croaker, Micropogonias undulatus (Scianidae) in the Cape Hatteras region. J Fish Biol 43:781-804

Valtonen ET, Pulkkinen K, Poulin R, Julkunen M (2001) The structure of parasite component communities in brackish water fishes of the north-eastern Baltic Sea. Parasitology 112:471-481

Vidal-Martínez V, Aguirre-Macedo L, Sholz T, González-Solis D, Mendoza-Franco F (2002) Atlas de los helmintos parásitos de cíclidos de México. Instituto Politecnico Nacional, México, p 183

Winter-Howard A (1959) Some trematodes from fishes of the Mexican and adjoining California Pacific, with notes on the distribution of eastern Pacific fish trematodes. Ph. D. Thesis, University of Southern California, p 198

Yamaguti S (1961) Systema Helminthum. III. Nematodes. Interscience Publishers, INC, New York, p 1261

Yamaguti S (1963) Systema Helminthum. Vol. IV: Monogenea and Aspidocotylea. Interscience Publishers, New York, p 381

Yamaguti S (1971) Synopsis of digenetic trematodes of vertebrates, vol I. Keigaku Publishing Co, Tokio Japan, p 1074 